\title{
PERAN BUDAYA ORGANISASI DALAM MENGOPTIMALKAN EFEKTIFITAS DAN EFISIENSI STRATEGI ORGANISASI
}

\author{
Muksin Wijaya \\ Sekolah Tinggi Manajemen Informatika dan Komputer LIKMI \\ Jl. Ir. Juanda 96 Bandung 40132 \\ E-mail : muksin.wj@gmail.com
}

\begin{abstract}
ABSTRAK
Strategi organisasi dan budaya organisasi adalah dua konsep yang paling mendasar di dalam ilmu manajemen. Berbagai penelitian sudah dilakukan dan secara secara empiris hasil dari setiap penelitian itu pada umumnya membuktikan bahwa strategi organisasi dan budaya organisasi memiliki hubungan yang sangat penting dan memberikan keuntungan bagi organisasi.

Strategi Organisasi dan Budaya Organisasi memiliki hubungan yang saling melengkapi dan timbal balik dalam upaya organisasi untuk untuk mencapai tujuannya. Budaya organisasi sangat mempengaruhi proses perumusan strategi organisasi, mulai dari formulasi strategi sampai kepada implementasi strategi tersebut.

Implementasi strategi organisasi akan mencapai hasil yang optimal, efektif dan efisien apabila difasilitasi dan diperkuat dan oleh tumbuhnya budaya organisasi yang baik dan kuat pula.
\end{abstract}

Kata Kunci : Budaya Organisasi, Strategi Organisasi.

\section{PENDAHULUAAN}

Keterkaitan Strategi organisasi dengan budaya organisasi pada perkembangan dewasa ini menjadi sangat diperhatikan baik oleh kalangan akademisi maupun di kalangan organisasi dan praktisi manajemen dalam organisasi. Di kalangan akademisi, persoalan strategi organisasi dan budaya organisasi semakin menarik untuk dikaji dan bahkan lebih lanjut seringkali dilakukan penelitian-penelitian dalam upaya mengoptimalkan implementasi strategi pada suatu organisasi. Di kalangan organisasi, strategi organisasi dan budaya organisasi semakin dilihat sebagai hal yang menarik dan penting untuk menjadi prioritas perhatian, keduanya semakin diperkuat untuk mencapai tujuan organisasi dengan lebih baik dan optimal.

Diharapkan dengan paparan di dalam jurnal ini, kita akan sama-sama dapat melihat dan semakin memahami hubungan interdependensi antara strategi organisasi dengan budaya organisasi dengan tidak mempersoalkan hubungan sebab akibat, seperti manakah yang lebih awal muncul antara strategi organisasi atau budaya organisasi, manakah yang menjadi penyebab dari yang lainnya, manakah yang menerima dampaknya, dan hal-hal lainnya yang bersifat sebab akibat.

Penelitian empiris terkini yang sudah dilakukan para ahli dan para akademisi cenderung menunjukkan strategi organisasi dan budaya organisasi memiliki hubungan interdependensi dan keduanya saling mempengaruhi secara timbal balik. (Klein A, 2011).

Budaya organisasi secara signifikan mempengaruhi proses perumusan strategi organisasi dan penetapan strategi organisasi, termasuk didalamnya persoalan implementasi strategi organisasi. Dengan kata lain, pemilihan strategi organisasi dan implementasi 
strategi organisasi dapat semakin menguatkan budaya organisasi atau merubah budaya organisasi. Lalu dengan cara bagaimana implementasi strategi organisasi dapat semakin menguatkan budaya organisasi atau bahkan merubah budaya organisasi? apa peranan budaya organisasi dalam pemilihan strategi organisasi dan implementasi strategi dalam organisasi?

Dengan paparan lanjut beriut ini diharapkan, kedua pertanyaan tersebut di atas dapat dijelaskan, dipahami dan dijawab dengan lebih menyeluruh. Jurnal ini akan mengajak para pembaca untuk lebih memahami terlebih dahulu tentang konsep dan pengertian strategi organisasi dan budaya organisasi yang dilengkapi dengan beberapa hasil penelitian empiris yang sudah dilakukan para ahli yang akan semakin memperkuat pemahaman kita tentang strategi organisasi dan budaya organisasiserta hubungan interdependensi yang terjadi di antara kedua hal tersebut.Selanjutnya keterkaitan dan hubungan strategi organisasi dan budaya organisasi akan dipaparkan lebih rinci, dan pada akhirnya akan diberikan rekomendasi manajemen perihal strategi organisasi dan budaya organisasi untuk dipertimbangkan bagi para pengambil kebijakan ataupun pengambil keputusan dalam mengorganisasikan strategi organisasi dan budaya organisasi.

\section{PEMAHAMANSTRATEGI ORGANISASI DAN BUDAYA ORGANISASI}

Strategi adalah hal penting yang harus durencanakan dan diputuskan dalam sebuah organisasi, bahkan persoalan strategi ini menjadi bagian yang krusial di dalam sebuah organisasi. Strategi merupakan jantung dari konsep manajemen stratejik. Strategi adalah langkah paling mendasar bagi organisasi di dalam mencapai tujuan organisasi. Strategi menunjukkan bagaimana kemampuan organisasi dalam menyelaraskan sumberdayanya dengan tuntutan perubahan lingkungan organisasi. Dengan Strategi, organisasi akan berjuang untuk mendayagunakan berbagai pilihan yang adauntuk dapat menghadapi ancaman-ancaman yang ada, dan mendayagunakan berbagai keunggulan organisasi untuk meminimalkan kelemahan-kelemahan organisasi dalam suatu kompetisi yang baik.

Pada perkembangan dewasa ini, strategi lebih bersifat dinamis dan strategi dipandang sebagai proses yang berkelanjutan, oleh sebab itu organisasi berupaya untuk dapat membentuk strateginya. Terdapat beberapa komponen dasar dimana organisasi memerlukan strategi, yaitu:

a. Kegiatan-kegiatan bisnis yang merupakan kegiatan utama organisasi

b. Keunggulan bersaing dari organisasi yang akan dicapai organisasi

c. Alokasi pendayagunaan sumberdaya organisasi untuk mencapai tujuan organisasi.

Dengan strategi, kegiatan utama organisasi, produk atau jasa yang ditawarkan, dan rencana organisasi dapat ditetapkan dan selanjutnya organisasi akan lebih mudah menentukan cara yang spesifik untuk memunculkan keunggulan bersaingnya.

Dalam menetapkan strategi bersaingnya, maka organisasi dihadapkan pada berbagai pilihan, diantaranya : pilihan pertama merujuk pada besarnya pasar yang akan dilayani atau difokuskan pada segmen pasar tertentu, pilihan kedua merujuk pada cara organisasi untuk mencapai keunggulannya dengan menjadi pemimpin pasar atau diferensiasi. Setelah pilihan-pilihan tersebut ditentukan, akhirnya organisasi dapat menetapkan pendayagunaan sumber daya yang ada (material, keuangan, SDM) dalam suatu implementasi kegiatan-kegiatan organisasi yang strategis.

Manajemen stratejik adalah suatu proses dalam memformulasikan dan mengimplementasikan strategi yang terdiri dari tiga tahap kegiatan utama, yaitu : kegiatan menganalisis, pemilihan strategi, implementasi strategi. Kegiatan analisis meliputi kegiatan dalam menganalisis misi dan tujuan organisasi, analisis factor-faktor lingkungan eksternal dan analisis factor-faktor lingkungan internal organisasi (kemampuan dan sumberdaya yang dimiliki organisasi). Pemilihan strategi meliputi kegiatan menyusun pilihan strategi, 
evaluasi dan pemilihan strategi. Pemilihan strategi ini akan berupa pemilihan atas berbagai alternative tanggapan organisasi terhadap situasi lingkungan organisasi yang perlu diselaraskan dengan kemampuan dan sumberdaya yang dimiliki organisasi. Implementasi strategi meliputi kegiatan pelaksanaan strategi melalui perencanaan atas berbagai kegiatan dan pengalokasian sumberdaya organisasi.

Setelah ketiga tahap utama tersebut dilakukan, penting bagi organisasi untuk melakukan penyesuaian-penyesuaian kembali terhadap strategi sehingga strategi organisasi benar-benar dapat diaplikasikan dan memberikan implikasi pada terjadinya perubahan kinerja dalam organisasi.Pada tahap akhir ini, manajemen perubahan mungkin perlu diterapkan dan menjadi bagian dari penerapan strategi dalam organisasi.

Budaya organisasidapat diartikan sebagai suatu sistem atas asumsi budaya, nilainilai yang dipegang, normadan sikap yang ditunjukkan dalam bentuk symbol-simbol dimana semua orang dalam organisasi mengembangkannya dan menerimanya. Budaya organisasi diharapkan dapat mereka yakini yang dapat membantu mereka dalam memaknai lingkungan organisasi tempat mereka berkarya dan bagaimana setiap orang dalam organisasi itu berperilaku di dalam organisasi tersebut. Berdasarkan pada pengertian ini, dapatlah kita simpulkan bahwa budaya organisasi akan terbentuk dari struktur kognitif bersama, berupa asumsi, nilai, norma yang dinyatakan dalam bentuk sikap dan perilaku.

Budaya organisasi memberikan konsekuensi kolektif pada interaksi social dari setiap orang di dalam organisasi. Kosekuensi kolektif ini akan berdampak pula pada pemecahan masalah organisasi dan dalam organisasimenyesuaikan diri dengan lingkungan eksternalnya.

Dengan budaya organisasi, pemecahan masalah dapat dilakukan bersama dengan lebih sistematis, dan hasilnya adalah untuk semuanya yang sudah terlibat sehingga kemudian akan terbentuklah struktur kognitif bersama yang dibagikan pada seluruh karyawan yang ada di organisasi dan juga para manajer. Dengan tertanamnya dan terbangunnya struktur kognitif bersama tersebut, maka para karyawan sudah memiliki arahan dan pedoman yang jelas di dalam menginterpretasikan lingkungan disekitar mereka dan bagaimana seharusnya mereka bersikap dan berperilaku di dalam organisasi tersebut.

Budaya organisasi sangat membantu para karyawan dan para manajer dalam memahami dan mengartikan konsep, sesuatu hal dan kejadian-kejadian yang terjadi baik di dalam organisasimaupun diluar organisasi. Dengan demikian mereka akan dapat lebih mudah dalam membuat keputusan, melakukan suatu tindakan, dan juga berinteraksi dengan lingkungannya.

Berdasarkan pada kenyataan tersebut, sekarang ini cenderung bahwa setiap kegiatan yang ada di dalam organisasi akan dimulai secara stratejik yang beberapa bagian pengambilan keputusannya akan dipengaruhi oleh budaya organisasi. Dalam berbagai penelitian yang sudah dilakukan para ahli, hasilnya menunjukkan bahwa strategi, system upah, struktur organisasi, system pengendalian organisasi, gaya kepemimpinan, dan elemen-elemen manajemen lainnya sangat di pengaruhi oleh budaya organisasi. Dengan alasan inilah maka dapat dipahami bahwa budaya organisasi merupakan factor yang signifikan atas kinerja organisasi bahkan merupakan factor penting dalam mencapai kesuksesan ataupun kehancuran organisasi.

Struktur kognitif bersama dalam organisasi merupakan jantung bagi organisasi karena struktur kognitif ini meliputi asumsi, nilai, norma, sikap dan perilaku. Asumsi yang terbangun dalam organisasi akan menjadi landasan dari interaksi dan hubungan di antara orang-orang yang ada di dalam organisasi. Nilai yang terbentuk dalam organisasi akan menjadi dasar bagi orang-orang dalam organisasi dalam bertindak. Norma yang dipegang organisasi akan menjadi aturan-aturan yang berlaku meskipun bentuknya tidak tertulis atau informal. Sikap dan keyakinan yang ada dalam organisasi akan menjadi bagian dari 
kebiasaan dari orang-orang dalam organisasi dan berinteraksi dengan sesame dalam organisasi ataupun daalam merespon setiap kejadian serta peristiwa yang terjadi dalam organisasi.Selain komponen kognitif diatas, di dalam budaya organisasi juga meliputi komponen simbolik yang berupa semua hal di dalam organisasi yang dapat dilihat secara kasat mata, dapat didengarkan, atau bahkan dapat dirasakan.

\section{MEMAHAMI HUBUNGAN MENDASAR ANTARA BUDAYA ORGANISASI DAN STRATEGI ORGANISASI}

Berbagai penelitian secara empiris menunjukkan bahwa ada hubungan yang kuat dan saling mempengaruhi secara timbal balik antara strategi organisasi dan budaya organisasi. Hubungan timbal balik antara strategi organisasi dan budaya organisasi akan tampak pada pengaruh budaya organisasi pada implementasi strategi, disamping bahwa strategi organisasi itu sendiri akan pula mempengaruhi pembentukan organisasi yang spesifik.

Untuk dapat memahami hubungan mendasar antara strategi organisasi dan budaya organisasi, kita perlu memahami terlebih dulu mekanisme dari pengaruh timbal balik tersebut dengan lebih mendalam. Kita perlu memahami terlebih dulu bagaimana pengaruh budaya organisasi di dalam menentukan dan mengimplementasikan strategi, dan bagaimana strategi organisasi berpengaruh terhadap budaya organisasi. Hal inilah yang selanjutnya akan dipaparkan pada bagian berikut ini.

\section{a. Pengaruh Budaya Organisasi terhadap Strategi Organisasi}

Budaya organisasi mempengaruhi strategi organisasi mulai dari proses perumusan strategi organisasi sampai pada implementasi strategi di dalam organisasi. Pada tahap perumusan strategi, budaya organisasi secara signifikan berpengaruh dalam hal pemilihan strategi organisasi, dan pada tahap implemntasi, budaya organisasi akan mempengaruhi dalam hal meminimalkan factor-faktor penghambat penerapan strategi tersebut. Pada kedua tahapan ini, budaya organisasi secara tidak langsung akan berpengaruh juga terhadap para pimpinan dan para pengambil keputusan dan kebijakan baik di tingkat manajemen puncak, manajemen menengah, manajemen bawah, bahkan kepada semua karyawan di dalam organisasi itu sendiri.

Pada tahap perumusan strategi, di dalamnya akan terdapat kegiatan untuk menganalisis lingkungan, menetapkan pilihan-pilihan strategi dan pemilihan strategi yang paling sesuai dengan organisasi. Pada tahap ini, budaya organisasi akan berpengaruh terhadap kerangka kerja yang akan dilakukan oleh para pimpinan atau para pengambil keputusan dan kebijakan. Asumsi budaya, nilai-nilai yang dianut serta norma-norma yang dipegang oleh seluruh orang yang ada di dalam organisasi akan diterapkan didalam membangun kerangka pikir, kerangka persepsi dan kerangka interpretasi serta pemahaman dari setiap orang di dalam organisasi tersebut, terutama terhadap orang-orang yang terlibat langsung di dalam tahap-tahap tersebut, yaitu dalam melakukan analisis lingkungan, memilih pilihan-pilihan strategi, menentukan strategi yang paling sesuai untuk diimplementasikan.

Secara umum asumsi, nilai-nilai dan norma-norma yang di pegang organisasi secara signifikan akan membentuk pola mental, termasuk pola mental para pimpinan dan para pengambil keputusan dan kebijakan organisasi. Pola mental ini akan berpengaruh pada persepsi dan interpretasi lingkungan organisasi yaitu intepretasi organisasi terhadap factor-faktor lingkungan internal dan interpretasi organisasi terhadap factor-faktor lingkungan eksternalnya. Pola mental berpengaruh juga pada kesimpulan organisasi akan 
strategi organisasi yang akan diterapkan, dan keputusan organisasi dalam memilih dan menetukan strategi organisasi yang paling pas bagi organisasi. Secara lebih rinci, budaya organisasi akan mempengaruhi strategi organisasi dalam hal-hal berikut ini:

- Budaya organisasi mempengaruhi cara manajemen organisasi di dalam mengumpulkan informasi dan menganalisis lingkungan internal dan lingkungan eksternal.

Budaya organisasi akan mempengaruhi organisasi di dalam menentukan informasi apa saja yang akan dikumpulkan dari lingkungan internal dan lingkungan eksternalnya.Dengan informasi yang terkumpul tersebut organisasi akan mendapatkan gambaran secara umum mengenai kekuatan, kelemahan, peluang dan ancaman yang mungkin sedang dihadapi dan perlu segera direspon. Budaya organisasi juga akan berpengaruh terhadap bentuk dari informasi yang akan kumpulkan, apakah itu bentuknya kualitatif atau bentuknya kuantitatif, berpengaruh juga terhadap prosedur formal atau informal yang akan dilakukan, bahkan berpengaruh terhadap sistematika dari pemindaian keseluruhan lingkungan organisasi. Pada organisasi yang menerapkannilai dan norma budaya yang terbuka terhadap lingkungannya, biasanya akan nampak pada perspektif organisasi yang cenderung akan melihat lingkungannya , terutama lingkungan eksternalnya secara lebih luas dan organisasi akan cenderung lebih fleksibel didalam menanggapi perubahan serta dinamika yang terjadi. Nilai-nilai dan norma-norma yang dipegang organisasi dalam hal ini juga berpengaruh terhadap prosedur organisasi didalam menndayagunakan sumberdayanya dan di dalam mengembangkan kemampuan organisasi.

- Budaya organisasi mempengaruhi cara pandang organisasi terhadap kejadian-kejadian yang terjadi di dalam organisasi.

Budaya organisasi (nilai-nilai dan norma) dalam hal ini akan mempengaruhi orangorang yang ada di dalam organisasi dalam melihat, mensikapi setiap peristiwa dan kejadian yang terjadi di dalam organisasi. Nilai dan norma yang baik akan mendasari orang-orang di dalam organisasi untuk lebih mudah mensikapi peristiwa yang terjadi secara lebih positif, hal ini dapat terjadi karena budaya organisasi sudah menjadi penyaring atas setiap informasi yang didapatkan. Respon yang positif akan memudahkan organisasi didalam mengimplementasikan strategi yang diterapkan, sedangkan persepsi negative malah akan mempersulit implementasi strategi.

- Budaya organisasi mempengaruhi cara interpretasi atas hal-hal yang terjadi di dalam lingkungan internal dan lingkungan eksternal.

Kemampuan interpretasi organisasi atas hal-hal yang terjadi baik di dalam lingkungan internalnya atau lingkungan eksternalnya, sangat dipengaruhi budaya organisasi, karena budaya organisasi inilah yang membentuk kemampuan tersebut.

- Budaya organisasi mempengaruhi organisasi di dalam memilih strateginya.

Berdasarkan persepsi atas lingkungan dan sumberdaya yang dimiliki, maka strategi dipilih yang paling sesuai dengan organisasi. Nilai-nilai dan norma yang dipegang organisasi akan turut mempengaruhi organisasi didalam pemilihan strategi.

Dengan berbagai pengaruh tersebut, maka dapat dipahami bahwa budaya organisasi memiliki peran yang penting di dalam strategi organisasi, mulai dari analisis strategis, sampai pada implementasi strategi. Nilai-nilai dan norma yang ada di dalam busaya organisasi ternyata berpengaruh terhadap optimalisasi pencapaian hasil strategi organisasi terutama di dalam implementasi strategi. Budaya organisasi berpengaruh pula terhadap 
kualitas pengambilan keputusan dan kebijakan yang dilakukan oleh manajemen organisasi, mulai dari manajemen puncak sampai kepada manajemen bawah.

Selain hal tersebut diatas, ada satu sisi dimana mungkin saja terjadi bahwa budaya organisasi tidak selaras dengan strategi organisasi. Pada kasus seperti ini biasanya budaya organisasi akan menjadi hambatan bagi implementasi strategi. Ketidakselarasan antara budaya organisasi dengan strategi organisasi dapat terjadi karena berbagai sebab dan alasan, salah satunya kerap terjadi karena tekanan lingkungan yang memaksa pengambil keputusan dan kebijakan untuk merubah apa yang ada saat ini, dan apa yang dirubah tidak dapat diterima oleh budaya organisasi. Ketidakselarasan antara budaya organisasi dan strategi organisasi kadang dapat terjadi ketika manajemen baru mengambil alih organisasi dimana pimpinan dan orang-orang yang terlibat didalam perubahan ini berasal dari luar organisasi. Konsekuensi dari ketidakselarasan budaya organisasi dan strategi organisasi akan menyebabkan pula ketidakselarasan operasional organisasi dengan asumsi budaya, nilai-nilai, norma yang dianut oleh orang-orang di dalam organisasi. Pada hampir semua kasus ketidakselarasan budaya organisasi dan strategi organisasi akan mengakibatkan munculnya berbagai hambatan terutama di dalam proses implementasi strategi, dan hambatan ini merupakan resiko budaya yang perlu diperhatikan.Lalubagaimana alternatif respon organisasiterhadap ketidakselarasan antara budaya organisasi dan strategi organisasi?

Ada beberapa alternatif respon yang dapat dilakukan organisasi bilamana terjadi ketidakselaran antara budaya organisasi dan strategi organisasi, diantaranya :

- Mengabaikan budaya organisasi.

Alternative respon ini kurang dapat disarankan pada organisasi dimana budaya organisasisudah tertanam kuat, namun alternative respon ini masih dapat disarankan sebagai pemecahan masalah sesaat atau jangka waktu yang singkat saja. Untuk jangka waktu yang panjang, pengabaian budaya organisasi malah akan menimbulkan persoalan baru yang lebih besar.

- Memodifikasi budaya organisasi untuk dapat beradaptasi dengan strategi.

Alternatif respon ini dapat dipertimbangkan untuk diterapkan pada situasi dimana manajemen yang baru melakukan modifikasi budaya organisasi agar dapat beradaptasi dengan strategi organisasi yang baru. Dengan memodifikasi diharapkan budaya organisasi dapat menyesuaikan dengan strategi yang baru. Meskipun demikian, alternative respon ini masih memiliki resiko yang tinggi. Paling tidak bahwa dengan alternative respon ini perubahan budaya organisasi dapat disesuaikan dengan waktu yang diperlukan strategi untuk dapat diimplementasikan. Situasi akan jauh lebih mudah apabila budaya berhasil dirubah, dan manajemen tinggal melakukan penyesuaian-penyesuai kecil untuk nilai-nilai dan norma-norma yang baru.

- Memodifikasi strategi organisasi untuk dapat beradaptasi dengan budaya organisasi.

Alternatif respon ini dapat diterapkan bilamana tidak ada tekanan apapun diantara budaya organisasi dan strategi organisasi.

- Merubah rencana implementasi strategi

Alternatif respon ini diterapkan apabila strategi organisasi yang baru lebih diutamakan oleh organisasi dan budaya organisasi tidak dapat beradaptasi dengan strategi organisasi yang baru tersebut. Rencana implementasi strategi dapat dirubah dan elemen-elemennya dapat disesuaikan agar lebih dapat diterima oleh budaya organisasi. 


\section{b. Pengaruh Strategi Organisasi terhadap Budaya Organisasi}

Pada paparan sebelumnya, kita sudah memahami pengaruh budaya organisasi terhadap perumusan strategi dan implementasi strategi, selanjutnya akan dipaparkan pengaruh strategi organisasi terhadap budaya organisasi.

Pengaruh strategi organisasi terhadap budaya organisasi bergantung pada kesesuaian nilai-nilai dan norma yang dipegang organisasi. Apabila strategi organisasi yang diterapkan secara konsisten selaras dengan budaya organisasi, maka strategi organisasi akan semakin memperkuat nilai-nilai organisasi, dan hal ini biasanya dilakukan melalui proses institusionalisasi, dimana strategi organisasi dijadikan sebagai sesuatu yang formal dalam organisasi.

Implementasi strategi organisasi memerlukan srangkaian kegiatan yang bersifat operasional yaitu berupa pekerjaan dan tugas tertentu yang perlu dilakukan oleh para karyawan atau para manajer. Ketika pekerjaan dan tugas tersebut dilakukan, tentu saja akan didasarkan pada asumsi, nilai-nilai dan norma yang ada di dalam organisasi sebagai budaya organisasi. Dalam hal ini berarti implementasi strategi akan memperkuat budaya organisasi melalui pelaksanaan tugas-tugas dan pekerjaan yang dilakukan oleh karyawan dan para manajer tersebut. Kadang implementasi strategi organisasi dapat pula menghasilkan dan membentuk budaya organisasi yang baru pula.

\section{KESIMPULAN DAN REKOMENDASI}

Berdasarkan paparan diatas, maka dapat disimpulkan bahwa strategi organisasi dan budaya organisasi berkaitan dan berpengaruh satu dengan lainnya secara timbale balik, dan keduanya apabila berjalan secara baik dan selaras akan dapat memberikan keuntungan bagi organisasi.

Budaya organisasi mempengaruhi strategi organisasi mulai dari tahap formulasi sampai dengan tahap implementasi. Budaya organisasi akan mempengaruhi tahap formulasi strategi dalam hal pembentukan pola pemahaman dan pola pemaknaan organisasi atas perubahan yang terjadi di dalam lingkungan internal dan lingkungan eksternal. Budaya organisasi mempengaruhi manajemen organisasi di dalam pengumpulan informasi yang berkaitan dengan lingkungannya untuk kemudian dipakai sebagai pertimbangan organisasi didalam pengambilan keputusan dan kebijakan organisasi.

Strategi organisasi mempengaruhi budaya organisasi melalui institusionalisasi budaya organisasi, dah hal ini tergantung kepada keselarasannya dengan nilai-nilai dan norma yang dipegang organisasi. Apabila tugas dan pekerjaan yang dituntut di dalam strategi organisasi dapat berjalan dengan baik dan sesuai dengan budaya organisasi, maka artinya strategi organisasi sudah memperkuat budaya organisasi atau bahkan sebaliknya.

Rekommendasi mendasar untuk manajemen organisasi berkenaan dengan hubungan strategi organisasi dengan budaya organisasi adalah setiap organisasi perlu menemukan cara yang pas untuk dapat menyelaraskan strategi organisasi dengan budaya organisasinya. Hal ini dapat dilakukan dengan banyak cara, diantaranya :

- Di dalam tahap formulasi strategi, manajemen perlu mengingat asumsi budayanya, nilai-nilai dan norma yang dipegang oleh organisasi.

- Manajemen perlu memahami cara terbaiknya dalam merubah budaya organisasinya dengan perencanaan yang sematang-matangnya. 


\section{DAFTAR PUSTAKA}

Brown,A. (1998), Organizational Culture.

Edgar H. Schein, (2010), Organizational Culture and Leadership.

Klein A., (2011), Corporate Culture: its value as a resource for competitive advantage, Journal of Business Strategy, Vol 32, No.2, p.21-28.

Pabundu Tika, (2006), Budaya Organisasi dan Peningkatan Kinerja Organisasi

Wilderom C. et al. (2000), Organizational Culture as a Predictor of Organizational Performance. 